\title{
Osmometric and Water-Transporting Properties of Guinea Pig Cardiac Myocytes
}

\author{
Toshitsugu OGURA, Sunao IMANISHI, and Toshishige SHIBAMOTO \\ Second Department of Physiology, Kanazawa Medical University, \\ Uchinada-machi, Kahoku-gun, Ishikawa, 920-0293 Japan
}

\begin{abstract}
To elucidate the mechanism of water flux across heart cell membranes, osmotically induced volume changes and sarcolemmal water permeability were evaluated in isolated guinea pig ventricular myocytes by videomicroscopic measurements of cell surface dimensions. Superfusion with anisosmotic solution (0.5-4 times normal osmolality) caused a rapid ( $<3$ min to new steady state) and reversible cell swelling or shrinkage mainly because of proportional changes in cell width and thickness. The van't Hoff relationship between relative cell volume and the reciprocal of relative osmolality was linear and predicted an apparent osmotically dead space of $\sim 35 \%$ cell volume. The osmotic water permeability coefficient $\left(P_{\mathrm{f}}\right)$ measured from the time course of cell swelling/shrinkage was $\sim 22 \mu \mathrm{m} \cdot \mathrm{s}^{-1}$ at $35^{\circ} \mathrm{C}$. Arrhenius activation energy $\left(E_{\mathrm{a}}\right)$, a measure of the energy barrier to
\end{abstract}

water flux, was $\sim 3.8 \mathrm{kcal} \cdot \mathrm{mol}^{-1}$ between 11 and $35^{\circ} \mathrm{C}$; this value is equivalent to $E_{\mathrm{a}}$ for free-water diffusion in bulk solution $\left(\sim 4 \mathrm{kcal} \cdot \mathrm{mol}^{-1}\right)$. Treatment with $0.1 \mathrm{mM} \mathrm{Hg}^{2+}$, a sulfhydryl-oxidizing reagent, reduced $P_{f}$ by $\sim 90 \%$, and the sulfhydryl-reducing reagent dithiothreitol $(10 \mathrm{mM})$ antagonized the inhibitory action of $\mathrm{Hg}^{2+}$. $E_{\mathrm{a}}$ measured from $\mathrm{Hg}^{2+}$-treated myocytes (12.3 $\mathrm{kcal} \cdot \mathrm{mol}^{-1}$ ) was in the range of that for diffusional water movement through the lipid bilayers $\left(>10 \mathrm{kcal} \cdot \mathrm{mol}^{-1}\right)$. Although the observed $P_{f}$ is small in magnitude, both the low $E_{\mathrm{a}}$ and the sulfhydryl-related modifications of $P_{f}$ are characteristic of channel-mediated water transport. These data suggest that water channels form a major conduit for water crossing the sarcolemma of guinea-pig heart cells. [Japanese Journal of Physiology, 52, 333-342, 2002]

Key words: cell volume, membrane water permeability, water channel, cardiac myocyte, osmolality.

All animal cells undergo volume expansion or shrinkage because of water flux driven by transmembrane osmotic gradients. The osmotically obliged water moves into and out of the cells primarily by diffusion through the membrane lipid bilayers [1, 2]. Because water movement is constrained by membrane fluidity and lipid organization, the diffusional water transport is small in magnitude $\left(<50 \mu \mathrm{m} \cdot \mathrm{s}^{-1}\right)$ and characterized by a high $\left(>10 \mathrm{kcal} \cdot \mathrm{mol}^{-1}\right)$ Arrhenius activation energy $\left(E_{\mathrm{a}}\right)$, a measure of the energy barrier to water flux [1-3]. In specialized tissues, such as renal tubules, eye lens, inner ear, and choroid plexus, membrane water permeability is greatly enhanced by the expression of the channel-forming protein aqua- porin [3-5]. The expression of water channels is not localized in region where high water permeability is required; it is now established that aquaporin molecules are abundant throughout animal tissues $[6,7]$. Recently, diffuse distributions of aquaporin molecules have been identified in several cardiac preparations by immunohistochemical approaches [6-9]. However, the functional significance of their presence in tissues serving a non-water-transporting role is still unclear.

The purpose of this study was to evaluate osmotically induced volume change and sarcolemmal water flux of guinea pig ventricular myocytes. Cell surface dimensions were measured by digital videomicroscopy, and the osmotic water permeability coeffi- 
cient $\left(P_{\mathrm{f}}\right)$ was obtained from the time course of cell swelling and shrinkage in response to rapidly imposed osmotic gradients. The results demonstrate that the myocytes exhibit osmometer-like behavior with an apparent osmotically dead space of nearly one-third of their volume. The observed $P_{\mathrm{f}}$ is small $\left(\sim 22 \mu \mathrm{m} \cdot \mathrm{s}^{-1}\right)$, but $E_{\mathrm{a}}$ is as low as the value for free water diffusion $\left(\sim 4 \mathrm{kcal} \cdot \mathrm{mol}^{-1}\right)$. These data, together with the pharmacological characteristics of $P_{\mathrm{f}}$, suggest that channel-mediated water transport plays a key role in the osmosis of guinea pig cardiac myocytes.

\section{MATERIALS AND METHODS}

Cell preparation. Experiments were performed in accordance with the Guiding Principles for the Care and Use of Animals approved by the Council of the Physiological Society of Japan. Guinea pigs (250-350 g) were anesthetized with sodium pentobarbital $\left(50 \mathrm{mg} \cdot \mathrm{kg}^{-1}\right.$, I.P.). Hearts were quickly excised, and single ventricular myocytes were enzymatically isolated as described previously [10]. In brief, the excised hearts were mounted on a Langendorff column and perfused $\left(37^{\circ} \mathrm{C}\right)$ with $\mathrm{Ca}^{2+}$-free Tyrode's solution containing collagenase $\left(\sim 0.1 \mathrm{mg} \cdot \mathrm{ml}^{-1}\right.$; Yakult, Tokyo, Japan). The cells were dispersed and maintained in a modified "KB" storage solution at $4^{\circ} \mathrm{C}$. A few drops of cell suspension were placed in a $0.25-\mathrm{ml}$ glass-bottomed chamber mounted on an inverted microscope (Diaphot-TMD, Nikon, Tokyo, Japan), and superfused $\left(3-4 \mathrm{ml} \cdot \mathrm{min}^{-1}\right)$ with bathing solution at $35^{\circ} \mathrm{C}$, unless otherwise noted. Only rod-shaped quiescent cells with smooth contours were selected for study.

Solutions. Normal Tyrode's solution contained (mM) $\mathrm{NaCl} 140, \mathrm{KCl} 5.4, \mathrm{CaCl}_{2} 1.8, \mathrm{MgCl}_{2} 1$, glucose 10, and HEPES 5 (pH 7.4 with $\mathrm{NaOH}$ ). Isosmotic (1T) Tyrode's solution was made by replacing $70 \mathrm{mM} \mathrm{NaCl}$ with $140 \mathrm{mM}$ sucrose (319 mosmol $\cdot \mathrm{kg}^{-1}$ ). Hyperosmotic $1.5 \mathrm{~T}, 2.2 \mathrm{~T}, 2.8 \mathrm{~T}$, and $4 \mathrm{~T}$ solutions were made by adding $140-750 \mathrm{mM}$ sucrose to the 1T solution $(485,689,900$, and $1,235 \mathrm{mosmol} \cdot \mathrm{kg}^{-1}$, respectively); Hyposmotic $0.5 \mathrm{~T}$ solution was made by omitting sucrose (166 mosmol $\cdot \mathrm{kg}^{-1}$ ), and $0.75 \mathrm{~T}$ solution was made by adding $70 \mathrm{mM}$ sucrose $\left(240 \mathrm{mosmol} \cdot \mathrm{kg}^{-1}\right)$ to the $0.5 \mathrm{~T}$ solution. $\mathrm{Cl}^{-}$-free solution was made by the equimolar substitutions of $\mathrm{MgSO}_{4}$ for $\mathrm{MgCl}_{2}$ and of methanesulfonate for other $\mathrm{Cl}^{-}$. Storage solution contained (mM) $\mathrm{KOH} 90, \mathrm{KCl} 30, \mathrm{KH}_{2} \mathrm{PO}_{4} 30, \mathrm{MgSO}_{4} 3$, glutamic acid 70, taurine 20, glucose 20, EGTA 0.5, and HEPES 10 (pH 7.4 with $\left.\mathrm{KOH}, 310 \mathrm{mosmol} \cdot \mathrm{kg}^{-1}\right)$. The osmolalities of the solutions were verified with a freezing-point depression osmometer (OM-6050, Arkray, Kyoto, Japan), and the variation was $<10 \mathrm{mosmol} \cdot \mathrm{kg}^{-1}$ for a given type of the solution.

Cell dimensions. Myocyte images were captured on-line with a high-resolution CCD camera (HV-D28S, Nikon) and a Macintosh computer equipped with a video frame grabber at $\sim 0.25$ $\mu \mathrm{m} \cdot \mathrm{pixel}^{-1}$ resolution and analyzed with image-processing software (NIH Image, National Institutes of Health, Bethesda, MD, USA). Halos around the cell images were minimized by using Hoffman modulation contrast optics (Modulation optics, Greenvale, NY, USA) attached to the microscope, and digital image processing (e.g., filtering and thresholding) was used to optimize the identification of cell profiles when appropriate. The borders of cell images were manually traced with a tablet-type pointing device, and the cell area was measured by counting included pixels. Cell length was measured as the longest axis to obtain the minimum average cell width calculated as area/length. Cell thickness was obtained by focusing at the top and bottom surfaces of myocytes and measured as the distance between the two focal planes by averaging 3-5 measurements for each myocyte. To unambiguously identify the top and bottom surfaces, alumina particles (diameter 1-2 $\mu \mathrm{m}$, Sumitomo Chemical, Tokyo, Japan) placed on the myocyte and the adjacent floor of the chamber were used as a marker.

The reproducibility of the cell width, length, and area measurements was assessed by repeatedly (10 times) tracing and measuring the same images recorded from 10 cells; the deviation of each measurement from the mean averaged $0.94 \pm 0.07 \%$ for width, $0.55 \pm 0.04 \%$ for length, and $1.29 \pm 0.09 \%$ for area. To assess cell thickness measurement, a roving "live" microelectrode filled with $3 \mathrm{M} \mathrm{KCl}$ (tip resistance 40-100 M $\Omega$ ) and connected to a high-input impedance amplifier was held by the headstage of a hydraulic micromanipulator (WR-3, Narishige, Tokyo, Japan) and moved vertically downward until a small $(<1 \mathrm{mV})$ deflection indicated contact with the cell surface. This measurement was read from the scale on the micromanipulator knob and subtracted from the level read when the microelectrode tip touched the floor of the bath (1-3 mV deflection); data were taken as the difference between the floor and 4-6 measurements from different areas of the cell. Cell thickness measurements were made by the focusing method after roving microelectrode measurements; the difference was $7.7 \pm 1.3 \%$ of the mean $(n=25)$.

Sarcolemmal water permeability. The osmotic permeability coefficient $P_{\mathrm{f}}$, which measures the ability of water to penetrate biological membranes, 
was calculated as described by Solomon [11] and Agre et al. [12] from the time course of cell swelling and shrinkage in response to a step change in osmotic gradient across the membrane:

$$
P_{\mathrm{f}}=\frac{V_{0} \cdot \mathrm{d} V_{\mathrm{rel}} / \mathrm{d} t}{S \cdot V_{\mathrm{w}} \cdot \Delta \pi}
$$

where $V_{0}$ is the absolute volume under control isosmotic conditions, $\mathrm{d} V_{\text {rel }} / \mathrm{d} t$ is the rate of change in the relative cell volume $V_{\text {rel }}$ as a function of time (see Fig. $5), S$ is the cell surface area, and $V_{\mathrm{w}}$ is the molar volume of water $\left(18 \mathrm{~cm}^{3} \cdot \mathrm{mol}^{-1}\right)$. The osmotic gradient $\Delta \pi$ is calculated as

$$
\Delta \pi=\pi_{\mathrm{i}}-\pi_{\mathrm{o}}=\frac{\left(1-V_{\mathrm{b}}\right) \cdot \pi_{\mathrm{i}(t=0)}}{\left(V_{\mathrm{rel}}-V_{\mathrm{b}}\right)}-\pi_{\mathrm{o}}
$$

where $\pi$ is the osmotic pressure with the subscripts o outside and $\mathrm{i}$ inside the cell, $\pi_{\mathrm{i}(t=0)}$ is the $\pi_{\mathrm{i}}$ at zero time, and $V_{\mathrm{b}}$ is the osmotically inactive volume fraction (see Fig. 3B). By assuming that $\pi_{\mathrm{i}}=\pi_{\mathrm{o}}$ in the steady state, $\pi_{\mathrm{i}}$ is taken as equal to $\pi_{\mathrm{o}}$ at zero time, and $\pi_{\mathrm{o}}$ refers to the osmotic pressure of the test solution. To estimate absolute cell volume and surface area, myocytes were assumed to be brick-shaped with a cell thickness/width ratio of 0.65 (see RESULTS).

The Arrhenius activation energy $E_{\mathrm{a}}$, defined by the relation $\ln P_{\mathrm{f}}=E_{\mathrm{a}} / R T+A$, where $R$ is the gas constant, $T$ is absolute temperature, and $A$ is an entropic term, was determined from the slope of a semilogarithmic plot of $P_{\mathrm{f}}$ vs. 1/temperature (Figs. 5B and 6Bb).

Statistics. The results are expressed as means \pm SEM, with $n$ indicating the number of experiments, and comparisons were made by using Student's $t$-test. An analysis of variance with Bonferroni correction was used for multiple comparisons. The differences were considered significant when $p<0.05$.

\section{RESULTS}

\section{Osmotic properties of guinea pig heart cells}

To verify analytical methods for $P_{\mathrm{f}}$ determination and to obtain constants included in Eqs. 1 and 2 (see METHODS), we performed a series of control experiments. The results described in the following subsections also help to characterize the osmotic properties of guinea pig ventricular myocytes.

\section{Cell dimensions under isosmotic condi-}

tions. To examine whether myocyte dimensions are stable under control 1T conditions, the cell length, width, and thickness were repeatedly measured during continuous superfusion with $1 \mathrm{~T}$ solution for $180 \mathrm{~min}$.

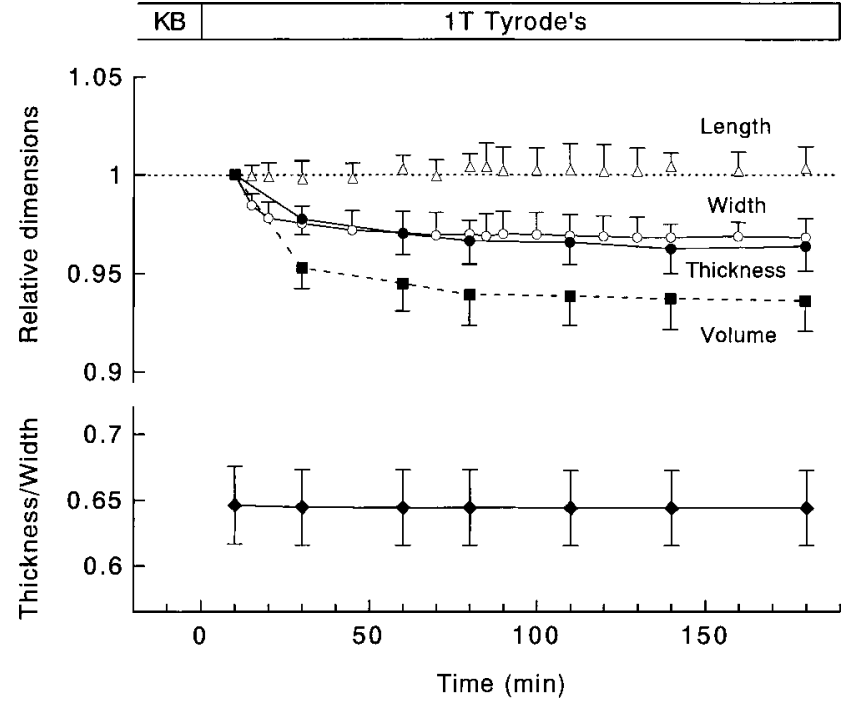

Fig. 1. Myocyte dimensions and volume during continuous superfusion with isosmotic 1T solution. Myocytes stored in KB solution were placed in a perfusion chamber and superfused with KB solution for $\sim 10$ min. Superfusion with $1 \mathrm{~T}$ Tyrode's solution began at $0 \mathrm{~min}$, and cell dimensions are expressed as relative values to the measurements at $10 \mathrm{~min}$; cell volume was calculated as length $\times$ width $\times$ thickness. $n=20-40$ myocytes.

After a 60-min superfusion, cell length was $120 \pm 2 \mu \mathrm{m}$, width $23 \pm 0.5 \mu \mathrm{m}$, thickness $15 \pm 0.5 \mu \mathrm{m}$, and the thickness/width ratio $0.65 \pm 0.02(n=100)$. Cell volume calculated as length $\times$ width $\times$ thickness (lwt) was $43 \pm 3 \mathrm{pl}(n=100)$. During $1 \mathrm{~T}$ superfusion, there were small time-dependent reductions in cell width and thickness, but no significant changes in cell length (Fig. 1). When normalized to the measurements at $10 \mathrm{~min}$, cell width declined to $0.97 \pm 0.01$, thickness to $0.96 \pm 0.01$, and $l w t$ volume to $0.94 \pm 0.02$ after $180 \mathrm{~min}(n=40)$. The decline in cell thickness closely paralleled the decline in cell width, with the thickness/width ratio being nearly constant at $\sim 0.65$ (Fig. 1, bottom). However, most changes in cell width and thickness occurred during the first $30 \mathrm{~min}$, and therefore cell volume at $180 \mathrm{~min}$ was not significantly different from its $30-\mathrm{min}$ value $(-1.6 \pm 1.0 \%$ change, $n=20$ ). This suggests that osmotic equilibrium across plasma membranes had been reached during $1 \mathrm{~T}$ superfusion. To minimize the influence of the time-dependent changes, all data reported below were obtained after $\sim 60 \mathrm{~min}$ equilibration period in $1 \mathrm{~T}$ solution. Note that the initial shrinkage was primarily due to a reduction in the cross-sectional area and therefore was unlikely to be due to moderate contracture because both myocyte twitch and contracture are characterized by shortening and widening $[13,14]$.

Osmotic cell swelling and shrinkage. Figure $2 \mathrm{~A}$ shows that superfusion with anisosmotic solu- 
Aa

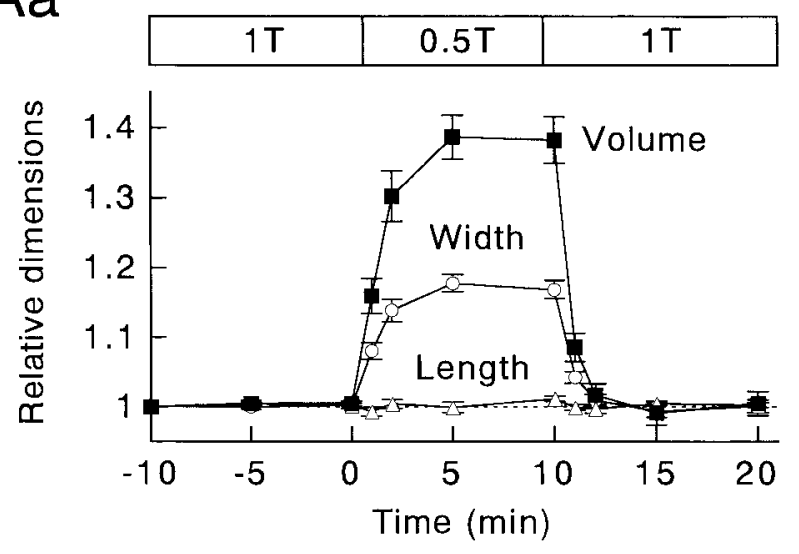

b

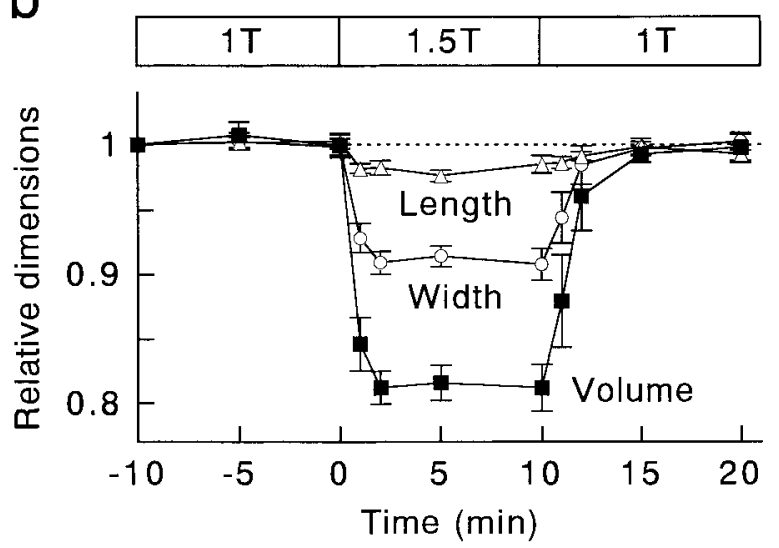

$\mathrm{Ba}$

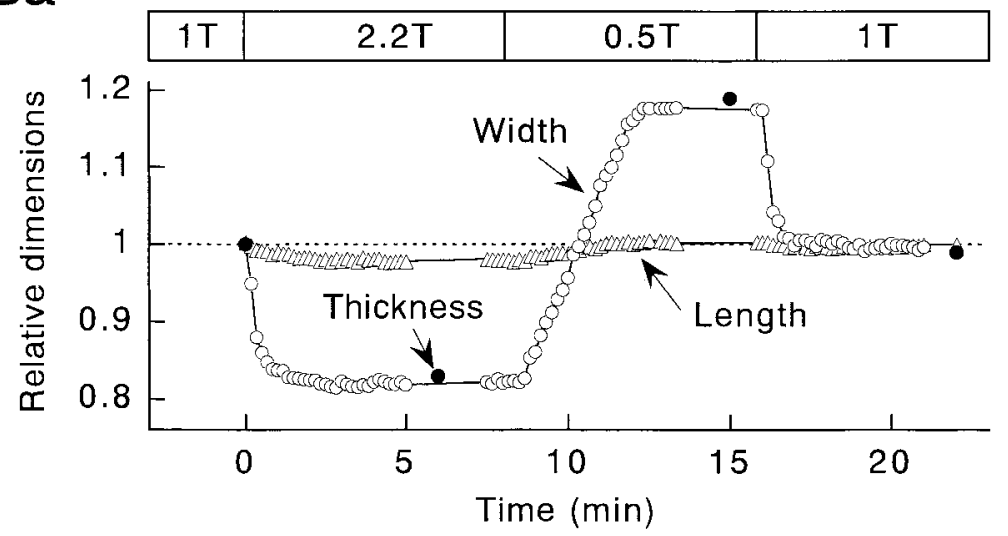

b
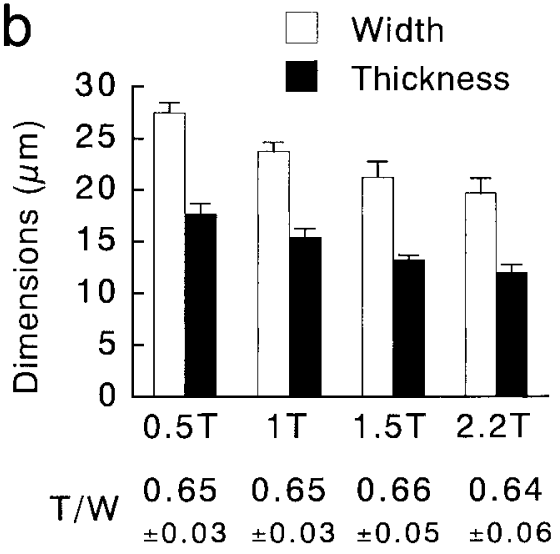

Fig. 2. Myocyte swelling and shrinkage under anisosmotic conditions. A: Time courses of the changes in cell dimensions before, during, and after superfusion with hyposmotic $0.5 \mathrm{~T}(\mathrm{Aa})$ or hyperosmotic $1.5 \mathrm{~T}(\mathrm{Ab})$ solution. Relative cell volume was calculated as length $\times(\text { width })^{2}$. 0.5T, $n=6$ myocytes; $1.5 \mathrm{~T}, n=8$ myocytes. B: Changes in cell thickness and width during anisosmotic challenges. Myocyte images were digitized at $10 \mathrm{~s}$ intervals, except for measurements of cell thickness at 6, 15, and $22 \mathrm{~min}(\mathrm{Ba})$. The thickness/width ratio $(T / W)$ in $\mathrm{Bb}$ was measured from each myocyte during sequential superfusion with 1T, 2.2T, $0.5 \mathrm{~T}$, and $1 \mathrm{~T}$ solutions. $n=11-33$ myocytes. tion caused a rapid and reversible cell swelling or shrinkage. Exposure to hyposmotic $0.5 \mathrm{~T}$ solution for 10 min significantly increased cell width to $1.17 \pm 0.01$ $(n=6)$, and relative cell volume calculated as length $\times(\text { width })^{2}\left(l w^{2}\right)$ was $1.38 \pm 0.07(p<0.05$ vs. $1 \mathrm{~T}$, $n=6$ ) (Fig. 2Aa). In contrast, hyperosmotic $1.5 \mathrm{~T}$ solution significantly decreased cell width to $0.91 \pm 0.01$ and $l w^{2}$ volume to $0.81 \pm 0.02(n=8)$ after $10 \mathrm{~min}$ (Fig. $2 \mathrm{Ab})$. Under both conditions, there were no significant changes in cell length $(1.01 \pm 0.003$ in $0.5 \mathrm{~T}, n=6$; $0.96 \pm 0.01$ in $1.5 \mathrm{~T}, n=8)$, suggesting the presence of longitudinal cellular load-bearing structures [14-16]. These new steady-states were attained in 2-5 min, and there were no later volume regulatory responses.

An estimation of cell volume by length $\times(\text { width })^{2}$ assumes that changes in cell width and thickness under anisosmotic conditions are proportional. The validity of the assumption was verified by measuring width and thickness from individual cells during se- quential superfusion with $1 \mathrm{~T}, 2.2 \mathrm{~T}$, and $0.5 \mathrm{~T}$ solutions. An example experiment depicted in Fig. 2Ba indicates that a myocyte narrowed and flattened to $\sim 0.82$ in $2.2 \mathrm{~T}$ solution and widened and thickened to $\sim 1.18$ in $0.5 \mathrm{~T}$ solution. A summary of the results in Fig. $2 \mathrm{Bb}$ indicates that neither swelling nor shrinkage significantly changed the thickness/width ratio $(0.65 \pm 0.03$ in $0.5 \mathrm{~T}, n=22 ; 0.66 \pm 0.05$ in $1.5 \mathrm{~T}, n=13$; $0.64 \pm 0.06$ in $2.2 \mathrm{~T}, n=11$ ) from that in $1 \mathrm{~T}$ solution $(0.65 \pm 0.03, n=33)$.

Osmometric behavior of myocytes. Myocytes were equilibrated in $1 \mathrm{~T}$ solution, then superfused for $10 \mathrm{~min}$ with one of the anisosmotic solutions. The steady-state data in Fig. 3A indicate that changes in cell length were modest compared to reductions in cell width, and that changes in cell thickness closely paralleled the changes in cell width. Relative $l w^{2}$ volumes of $1.38 \pm 0.02(n=16), 1.19 \pm 0.02$ $(n=7), 0.77 \pm 0.02(n=13), 0.66 \pm 0.03(n=10)$, and 

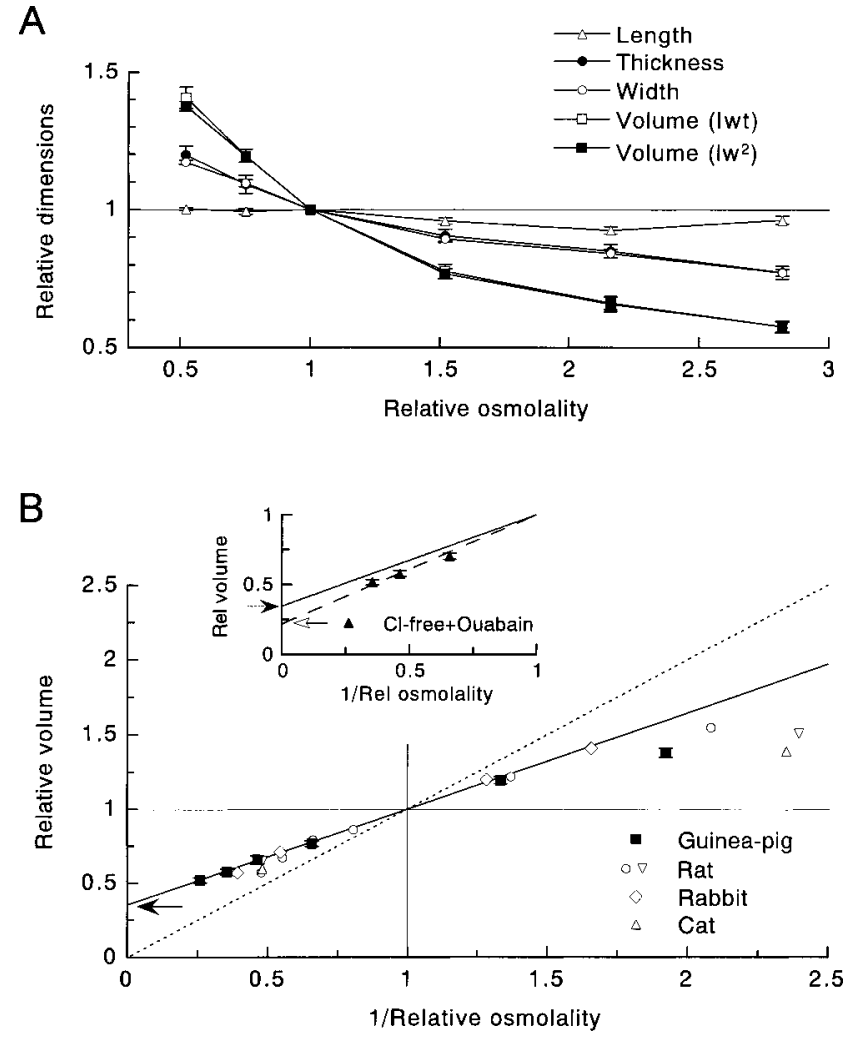

Fig. 3. Osmotically induced changes in myocyte parameters. A: Summary of changes in cell dimensions and calculated ( $/ W t$ and $/ W^{2}$ ) volumes after $10 \mathrm{~min}$ in anisosmotic solutions. $n=7-16$ myocytes. All data, except cell length under hyposmotic conditions, are significantly different $(p<0.001)$ from isosmotic values. B: A van't Hoff plot of relative $I W^{2}$ volume vs. the reciprocal of the relative osmolality of bathing solution. The straight line is a linear regression fit to mean data (closed squares, $n=5-13$ myocytes): $V_{\text {rel }}=$ $\left\{\left(1-V_{\mathrm{b}}\right) / \pi_{\text {rel }}\right\}+V_{\mathrm{b}}=\left(0.65 / \pi_{\text {rel }}\right)+0.35$, where $V_{\text {rel }}$ is the relative cell volume, $\pi_{\text {rel }}$ is the relative solution osmolality, and the intercept with the volume axis 0.35 (arrow) is an estimate of the osmotically inactive fraction $V_{\mathrm{b}}$. Also included are data from earlier studies on rat $[15,16]$, rabbit [17], and cat [16] ventricular myocytes. The dotted line illustrates the theoretical relationship for perfect osmometer behavior. The inset depicts van't Hoff data from myocytes treated with hyperosmotic $\mathrm{Cl}^{-}$-free $+10 \mu \mathrm{M}$ ouabain solutions $(n=10-12$ myocytes); the open arrow indicates the volume axis intercept of 0.22 .

$0.58 \pm 0.02(n=9)$ in $0.5 \mathrm{~T}, 0.75 \mathrm{~T}, 1.5 \mathrm{~T}, 2.2 \mathrm{~T}$, and $2.8 \mathrm{~T}$ solutions, respectively, were therefore nearly identical to those calculated with independent parameters (relative $l w t$ volume: $1.41 \pm 0.04,1.19 \pm 0.02,0.78 \pm 0.03$, $0.66 \pm 0.02$, and $0.57 \pm 0.02$ in the respective solutions).

Figure 3B depicts a van't Hoff plot of the $l w^{2}$ volume against the reciprocal of relative osmolality. One notable feature is that the myocyte volume (filled squares) did not change to the degree expected of a perfect osmometer (dotted line with intercept at zero cell volume), and an extrapolation of the regression line to the cell volume axis suggests a limiting value of 0.35 (arrow). Another feature is that the volume data obtained under $0.75 \mathrm{~T}$ through $4 \mathrm{~T}$ conditions were described by the van't Hoff relationship (see Fig. 3 legend for van't Hoff equation), whereas the $0.5 \mathrm{~T}$ data (rightmost square) was slightly smaller than predicted by the relationship. The data from earlier volumetric studies on rat [15, 16], rabbit [17], and cat [16] ventricular myocytes also exhibited similar trends (open symbols).

A common explanation for the deviation from the theoretical van't Hoff relationship is that a fraction of the cell volume is osmotically inactive $[15,17]$. To obtain additional information on this point, another group of myocytes were subjected to hyperosmotic challenges after inhibiting osmolyte fluxes via $\mathrm{Cl}^{-}$ transport and $\mathrm{Na}^{+}-\mathrm{K}^{+}$pumping, two processes that have been expected to contribute to cardiac cell volume regulation [17]. Under isosmotic conditions, a 10-min treatment with $\mathrm{Cl}^{-}$-free solution that contained $10 \mu \mathrm{M}$ ouabain caused no significant change in relative cell volume $(1.00 \pm 0.02, n=33)$. Subsequent exposures to hyperosmotic $\mathrm{Cl}^{-}$-free+ouabain mixtures caused larger shrinkage than that caused by the standard challenges, resulting in a steeper regression line with the volume intercept of 0.22 (Fig. 3B, inset). In summary, the van't Hoff relationship is helpful in interpolating between the measured points, but the volume intercept per se has little real meaning if compensatory ion fluxes occur during the measurement period. Because there are no clear-cut prescriptions to handle the nonzero volume intercept, the empirical value of 0.35 is used for $P_{\mathrm{f}}$ calculation (see Eq. 2), as in earlier study by others ( 0.34 for rabbit ventricular myocytes [18]).

\section{Water permeability of myocyte membranes}

Figure 4 shows an analysis of the time course of osmotic swelling with data from a representative myocyte exposed to a $0.5 \mathrm{~T}$ solution. Upon a switch from $1 \mathrm{~T}$ to $0.5 \mathrm{~T}$ solution, the myocyte rapidly swelled to a new steady volume of 1.38 , with the half-time $\left(t_{1 / 2}\right)$ of $\sim 35 \mathrm{~s}$ (corrected for the lag time because of solution exchange). The first derivative of relative volume $\left(\mathrm{d} V_{\text {rel }} / \mathrm{d} t\right)$ reached a maximum after $40 \mathrm{~s}$, and the osmotic gradient $(\Delta \pi)$ gradually declined during $0.5 \mathrm{~T}$ superfusion. The permeability coefficient $P_{\mathrm{f}}$ calculated from the peak (40 s) value of $\left(\mathrm{d} V_{\mathrm{rel}} / \mathrm{d} t\right) / \Delta \pi$ by the Eq. 1 (see METHODS) was $21.5 \mu \mathrm{m} \cdot \mathrm{s}^{-1}$. The data from similar experiments on 0.5T-induced swelling gave the averaged $P_{\mathrm{f}}$ of $23.6 \pm 1.9 \mu \mathrm{m} \cdot \mathrm{s}^{-1}(n=9)$ at $35^{\circ} \mathrm{C}$. 

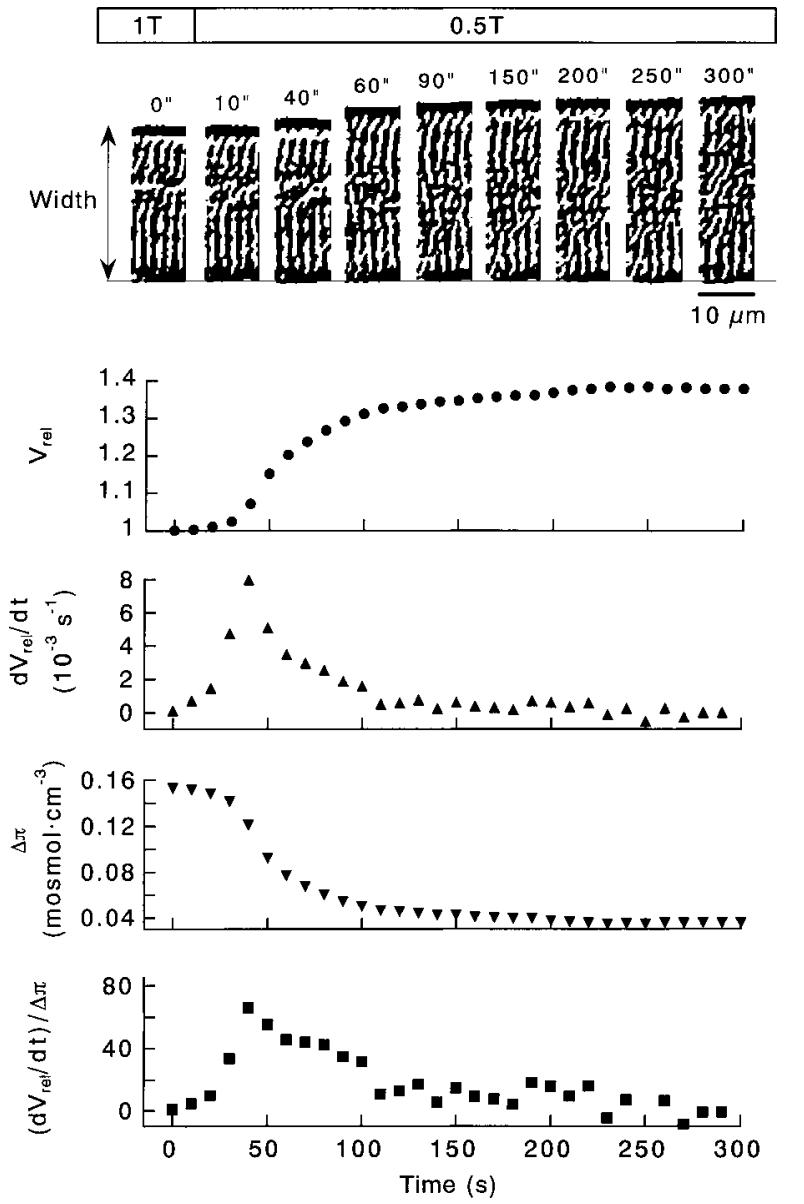

Fig. 4. Analysis of the time course of osmotic cell swelling using data from a representative myocyte. The top panel shows example images of the middle portion of the myocyte demonstrating an increase in cell width during 5 min superfusion with $0.5 \mathrm{~T}$ solution $\left(35^{\circ} \mathrm{C}\right)$. Sequential cell images were digitized at $10 \mathrm{~s}$ intervals to obtain relative $/ w^{2}$ volume $\left(V_{\text {rel }}\right)$, its first derivative $\left(d V_{\text {rel }} / d t\right)$, and the osmotic gradient $(\Delta \pi)$. The water permeability coefficient $P_{\mathrm{f}}$ was calculated from the peak $(40 \mathrm{~s})$ value of $\left.\left(\mathrm{d} V_{\text {rel }} / \mathrm{d} t\right) / \Delta \pi\right)$ by Eqs. 1 and 2 (see METHODS).

Water permeation across biological membranes is dependent on temperature [2-4]. As depicted in Fig. $5 \mathrm{~A}$, the rate of cell swelling and shrinkage was slower at lower temperatures: $t_{1 / 2}$ increased from $36.3 \pm 3.9 \mathrm{~s}$ $(n=9)$ at $35^{\circ} \mathrm{C}$ to $73.4 \pm 9.1 \mathrm{~s}(n=8)$ at $22^{\circ} \mathrm{C}$, and $112.1 \pm 13.4 \mathrm{~s} \quad(n=8)$ at $11^{\circ} \mathrm{C}$ for $0.5 \mathrm{~T}$-induced swelling, and from $8.7 \pm 0.7 \mathrm{~s}(n=5)$ at $35^{\circ} \mathrm{C}$ to $20.1 \pm 5.0 \mathrm{~s}(n=7)$ at $11^{\circ} \mathrm{C}$ for $2.2 \mathrm{~T}$-induced shrinkage. $P_{\mathrm{f}}$ obtained from these challenges was $23.6 \pm 1.9$ $(n=9), 12.6 \pm 3.3(n=8)$, and $8.0 \pm 1.5(n=8) \mu \mathrm{m} \cdot \mathrm{s}^{-1}$ for swelling at 35,22 , and $11^{\circ} \mathrm{C}$, respectively, and $19.8 \pm 1.4(n=5)$ and $7.2 \pm 1.2(n=7) \mu \mathrm{m} \cdot \mathrm{s}^{-1}$ for shrinkage at 35 and $11^{\circ} \mathrm{C}$, respectively. $P_{\mathrm{f}}$ calculated for cell shrinkage in response to greater osmotic gradient (4T) was $11.9 \pm 1.0(n=5)$ and $7.6 \pm 0.2 \mathrm{~s}(n=4)$ $\mu \mathrm{m} \cdot \mathrm{s}^{-1}$ at 22 and $11^{\circ} \mathrm{C}$, respectively.
Aa

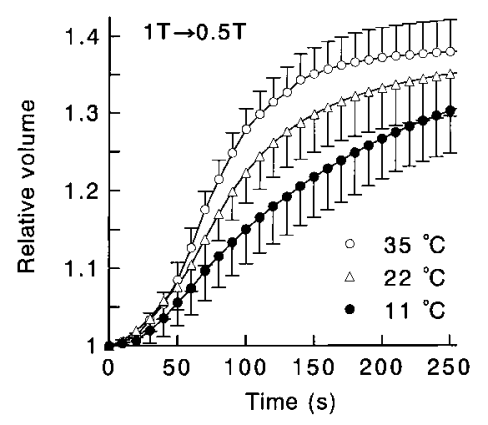

b

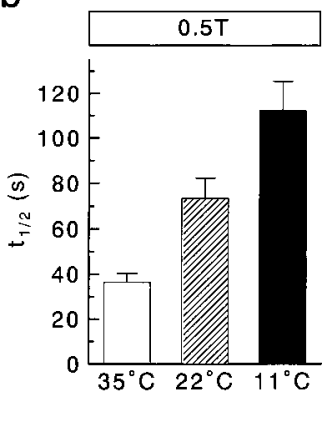

B

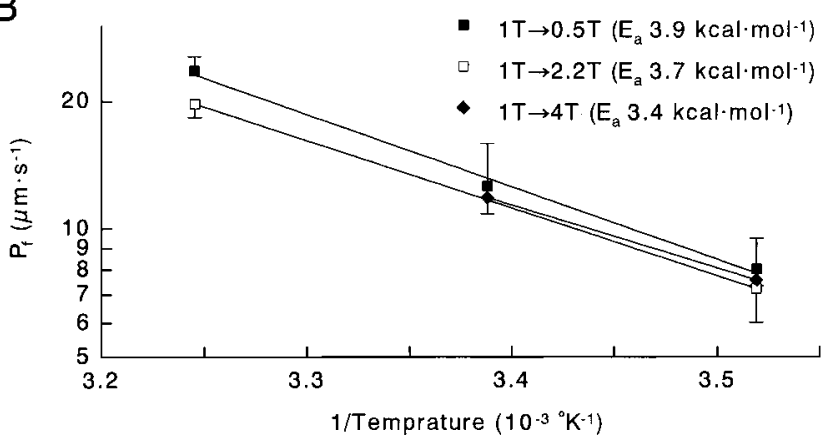

Fig. 5. Temperature dependence of osmotic swelling and shrinkage. A: Time course of cell swelling in $0.5 \mathrm{~T}$ solution (Aa) and half-time $\left(t_{1 / 2}\right)(\mathrm{Ab})$ at 11,22 , and $35^{\circ} \mathrm{C}$. The $t_{1 / 2}$ was measured by reference to quasi-steady-state (10 min) volume. B: Arrhenius plot of water permeability coefficient $\left(P_{\mathrm{f}}\right)$. The activation energy $\left(E_{\mathrm{a}}\right)$ given by the slope of the plot was $3.9,3.7$, and $3.4 \mathrm{kcal} \cdot \mathrm{mol}^{-1}$ under $0.5 \mathrm{~T}$, $2.2 \mathrm{~T}$, and $4 \mathrm{~T}$ conditions, respectively. $n=4-9$ myocytes.

The Arrhenius activation energy $E_{\mathrm{a}}$ provides a measure of the energy barrier to water movement across a membrane and is determined from the slope of a semilogarithmic plot of $P_{\mathrm{f}}$ vs. 1/temperature (Fig. 5B). $E_{\mathrm{a}}$ measured between 11 and $35^{\circ} \mathrm{C}$ was $3.9 \mathrm{kcal} \cdot \mathrm{mol}^{-1}$ for swelling in $0.5 \mathrm{~T}$ solution, $3.7 \mathrm{kcal} \cdot \mathrm{mol}^{-1}$ for shrinkage in $2.2 \mathrm{~T}$ solution, and $3.4 \mathrm{kcal} \cdot \mathrm{mol}^{-1}$ for shrinkage in $4 \mathrm{~T}$ solution. These values, which are equivalent to $E_{\mathrm{a}}$ for the self-diffusion of water in bulk solution $\left(\sim 4 \mathrm{kcal} \cdot \mathrm{mol}^{-1}\right)$, indicate that the temperature dependence of water transport across guinea pig heart cell membranes is relatively low in comparison with diffusion of water through lipid membranes $\left(>10 \mathrm{kcal} \cdot \mathrm{mol}^{-1}\right)[2-4]$.

\section{$\mathrm{Hg}^{2+}$ inhibition of osmotic cell swelling}

The weak temperature dependence of myocyte $P_{\mathrm{f}}$ suggests that water transverses the sarcolemma through water-filled pores. To obtain additional information on this point, the time course of osmotic swelling was investigated in myocytes treated with $\mathrm{Hg}^{2+}$, an inhibitor of pore-mediated water transport across cell membranes $[3,4,19]$. The results shown in 

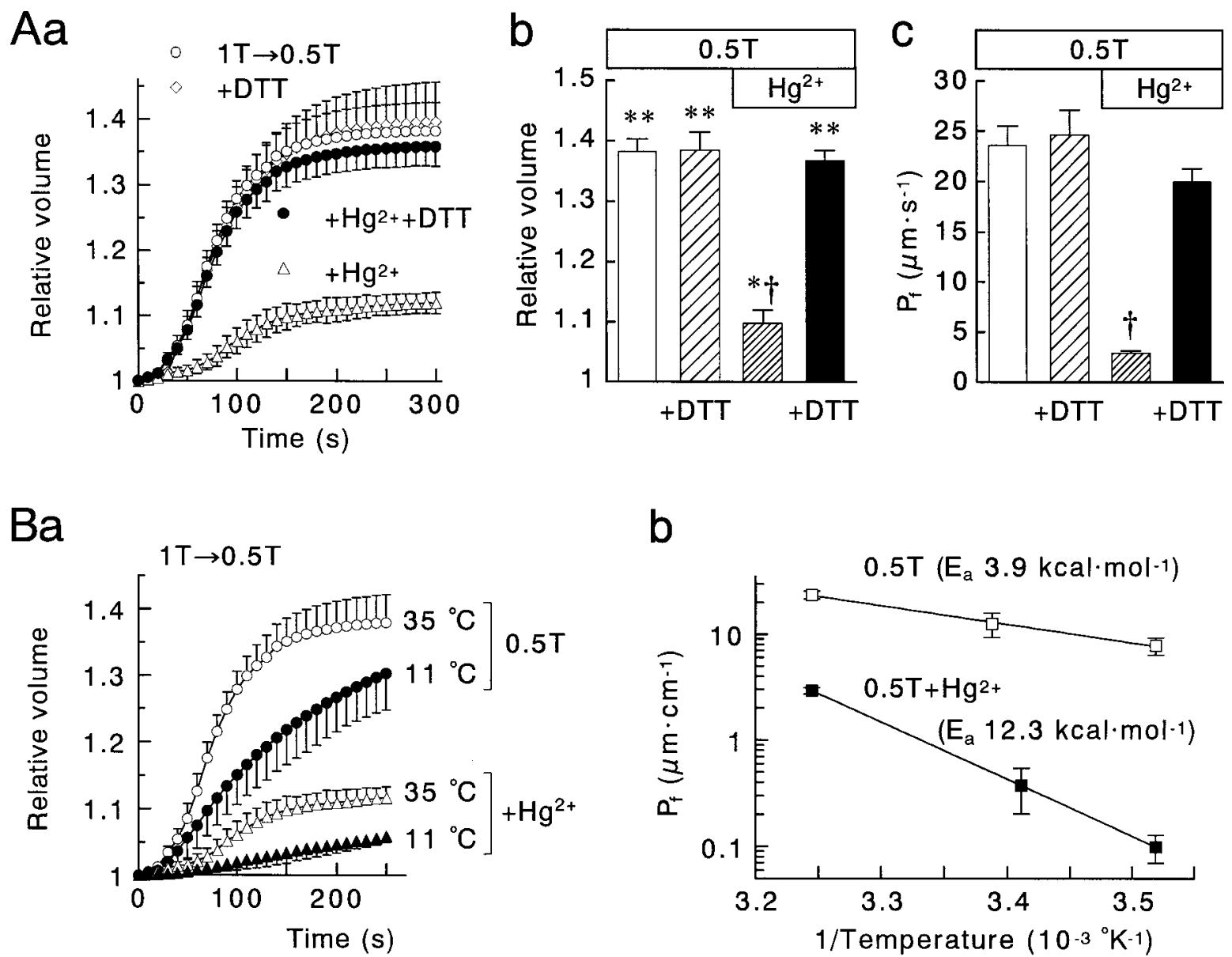

Fig. 6. $\mathrm{Hg}^{2+}$ inhibition of osmotic swelling and $\boldsymbol{P}_{\mathrm{f}}$ in 0.5T solution. A: Effects of $0.1 \mathrm{mM} \mathrm{HgCl}$ and $10 \mathrm{mM}$ dithiothreitol (DTT) on the time course of swelling (Aa), quasi-steady-state (10 min) volume $(A b)$, and $P_{f}(A c)$ at $35^{\circ} \mathrm{C}$. Myocytes were exposed to $0.5 \mathrm{~T}$, 0.5T+DTT, $0.5 \mathrm{~T}+\mathrm{Hg}^{2+}$, and $0.5 \mathrm{~T}+\mathrm{Hg}^{2+}+\mathrm{DTT}$ solutions. $n=5-9 \mathrm{my}-$ ocytes. ${ }^{*} p<0.05$ and ${ }^{* *} p<0.001$ vs. pre- $0.5 \mathrm{~T} ;{ }^{\dagger} p<0.001$ vs.

Fig. 6Aa indicate that treatment with $0.1 \mathrm{mM} \mathrm{HgCl}$ inhibited cell swelling during $0.5 \mathrm{~T}+\mathrm{Hg}^{2+}$ superfusion. Relative cell volume after $10 \mathrm{~min}$ in $0.5 \mathrm{~T}$ solution was significantly smaller in $\mathrm{Hg}^{2+}$-treated myocytes $(1.10 \pm 0.02, n=5)$ than in non- $-\mathrm{Hg}^{2+}$-treated myocytes $(1.38 \pm 0.02, n=9)$ (Fig. $6 \mathrm{~B})$. The calculated $P_{\mathrm{f}}$ in $\mathrm{Hg}^{2+}$-treated myocytes $\left(2.9 \pm 0.2 \mu \mathrm{m} \cdot \mathrm{s}^{-1}, n=5\right)$ was $\sim 8$ times smaller than that of non- $\mathrm{Hg}^{2+}$-treated myocytes $\left(23.6 \pm 1.9 \mu \mathrm{m} \cdot \mathrm{s}^{-1}, n=9\right)$ at $35^{\circ} \mathrm{C}$.

Mercurials are sulfhydryl-oxidizing reagents, and their biological actions can be antagonized by sulfhydryl-reducing agents $[3,4,19]$. As indicated by the closed symbols and bars in Fig. 6A, the inhibition of cell swelling by $0.5 \mathrm{~T}+\mathrm{Hg}^{2+}$ treatment was reversed by the reducing agent dithiothreitol (DTT, $10 \mathrm{mM}$ ), whereas DTT had little effect on swelling in the absence of $\mathrm{Hg}^{2+} . P_{\mathrm{f}}$ in myocytes exposed to $0.5 \mathrm{~T}+\mathrm{Hg}^{2+}+$ DTT solution $\left(20.0 \pm 1.3 \mu \mathrm{m} \cdot \mathrm{s}^{-1}, n=6\right)$ b

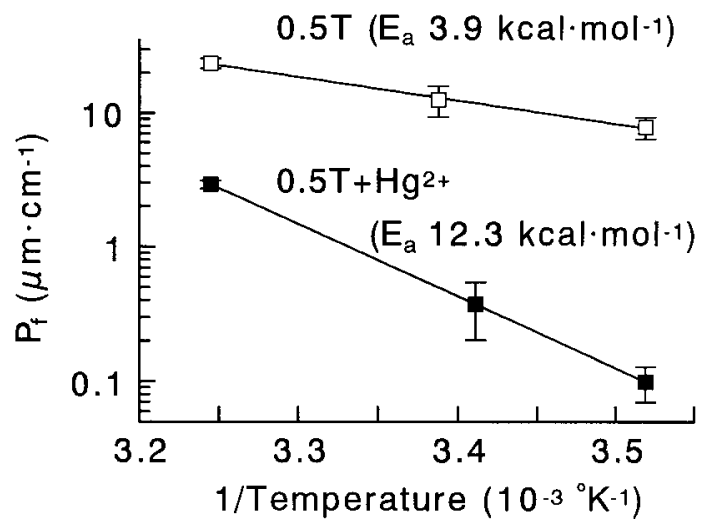

control 0.5T. B: Temperature dependence of $\mathrm{Hg}^{2+}$ actions on the time course of swelling $(\mathrm{Ba})$ and Arrhenius plot of $P_{\mathrm{f}}$ (Bb). Data were obtained from myocytes exposed to $0.5 \mathrm{~T}$ solution with and without $0.1 \mathrm{mM} \mathrm{Hg}^{2+}$ at $11-35^{\circ} \mathrm{C}$. The activation energy $\left(E_{\mathrm{a}}\right)$ was 3.9 and $12.3 \mathrm{kcal} \cdot \mathrm{mol}^{-1}$ in control and $\mathrm{Hg}^{2+}$-treated cells, respectively. $n=5-9$ myocytes.

was not significantly different than measured in nontreated myocytes (Fig. 2Ac). These results suggest that the $\mathrm{Hg}^{2+}$ inhibition of $P_{\mathrm{f}}$ is due to binding of the metal to sulfhydryl groups in proteins associated with water-traversing membrane pores.

If the primary pathway for osmotic water movement is the membrane pores, water flow remaining after blockade of the pores should exhibit higher temperature dependence, i.e., larger $E_{\mathrm{a}}$ [18]. To test this possibility, $P_{\mathrm{f}}$ was calculated from the time course of 0.5 T-induced swelling in $0.1 \mathrm{mM} \mathrm{Hg}^{2+}$-treated myocytes at 35 and $11^{\circ} \mathrm{C}$ (Fig. 6Ba). $E_{\text {a }}$ measured between 11 and $35^{\circ} \mathrm{C}$ was $12.3 \mathrm{kcal} \cdot \mathrm{mol}^{-1}$ (Fig. $6 \mathrm{Bb}$, closed symbols); this value is $\sim 3$-fold greater than that for non- $\mathrm{Hg}^{2+}$-treated myocytes $\left(3.9 \mathrm{kcal} \cdot \mathrm{mol}^{-1}\right.$; Fig. $6 \mathrm{Bb}$, open symbols) and is in the range of values for lipid membranes not containing functioning water channels $\left(8-15 \mathrm{kcal} \cdot \mathrm{mol}^{-1}\right)[1]$. 


\section{DISCUSSION}

The purpose of this study was to evaluate osmotically induced volume change and sarcolemmal water permeability of guinea pig ventricular myocytes. The results demonstrate osmometric properties of heart cells: (1) the unchanged cross-sectional geometry and the differential compliance in the radial and axial directions; (2) a linear van't Hoff behavior predicting the $\sim 35 \%$ osmotically dead volume; (3) the lack of evidence for a short-term volume compensation; (4) water permeability 5-20 times smaller than that of water-transporting tissues; and (5) the low $E_{\mathrm{a}}$ and the sulfhydryl-related modifications of $P_{\mathrm{f}}$ suggesting a channel-mediated water transport.

Osmotic cell swelling and shrinkage. Estimation of cross-sectional geometry is central to the calculation of myocyte volume. On the assumption that a myocyte is a rectangular parallelepiped, the mean volume of the myocyte was $43 \mathrm{pl}$; the calculated volumes are $34 \mathrm{pl}$ for an elliptical cylinder [14, 20], $54 \mathrm{pl}$ for a circular cylinder [15, 21, 22], and $68 \mathrm{pl}$ for a rectangular parallelepiped with equal width and thickness [17]. The last two are clearly erroneous, since guinea pig ventricular myocytes are brickshaped with the thickness/width ratio of $\sim 0.65$, and their cross-sectional geometry is unchanged after osmotic swelling and shrinkage.

The assumption on myocyte geometry has much importance to the determination of $P_{\mathrm{f}}$ because the surface/volume ratio is inversely proportional to $P_{\mathrm{f}}$ (see Eq. 1). The surface/volume ratio calculated for a brick-shaped myocyte with $120 \mu \mathrm{m}$ length, $23 \mu \mathrm{m}$ width, and $15 \mu \mathrm{m}$ thickness is $0.24 \mu \mathrm{m}^{2} \cdot \mu \mathrm{m}^{-3}$. If the cell surface area is estimated from membrane capacitance $\left(C_{\mathrm{m}}\right)$ of guinea pig ventricular myocytes $(152 \pm 5 \mathrm{pF}, n=80)$ and a specific $C_{\mathrm{m}}$ of $1 \mu \mathrm{F} \cdot \mathrm{cm}^{-2}$ [23], the ratio is $0.37 \mu \mathrm{m}^{2} \cdot \mu \mathrm{m}^{-3}$, and therefore $P_{\mathrm{f}}$ is $\sim 0.7$ times the values obtained by the standard calculation. The divergence may reflect the presence of membrane folding, invaginations, and T tubules [24], but these structures cannot be resolved with the present microscope arrangement.

Earlier studies on isolated cat [16], ferret [14], rabbit [17], and rat [14-16] ventricular myocytes have shown that changes in cell width under anisosmotic conditions were larger than the changes in cell length. Our measurements indicate that changes in cell width and thickness are proportional and much larger than the changes in cell length. This probably reflects directional differences in the elastic characteristics of the internal load-bearing structures (sarcolemma, myofilaments, cytoskeleton [14-16]), i.e., the compliance of a myocyte in the radial direction is uniform, but it is greater than its compliance in the longitudinal direction.

Changes in cell volume under anisosmotic conditions were less than expected from the van't Hoff relationship for the cells exhibiting perfect osmometric behavior. The volume intercept on the van't Hoff plot suggests that guinea pig ventricular myocytes have an apparent osmotically inactive fraction of $35 \%$. This estimate is in agreement with the values reported for rat (18\%) [15], cat (23\%, estimated from Tanaka et al.) [16], and rabbit (34\%) [17] ventricular myocytes. The indication of an inactive volume may mean that it is fixed, as in a cellular compartment; the volume occupied by nonaqueous materials (e.g., cell proteins, solute, membranous structures) and protein-bound water could behave as an osmotically dead space [15, 17], but it could also reflect a transmembrane redistribution of osmolytes in response to anisosmotic stress. There are grounds for expecting that volume-regulatory processes are activated in the myocytes: The hyperosmotic shrinkage of rabbit ventricular myocytes was larger in the presence of $\mathrm{Cl}^{-}$transport blockers or ouabain [17], and we observed more pronounced shrinkage under $\mathrm{Cl}^{-}$-free + ouabain conditions (Fig. $3 \mathrm{~B}$, inset). When the activity of these compensatory mechanisms is curtailed, guinea-pig cells may approach perfect osmometer status.

Membrane water transport. $P_{\mathrm{f}}$ of guinea pig ventricular myocytes $\left(\sim 22 \mu \mathrm{m} \cdot \mathrm{s}^{-1}\right.$ at $\left.35^{\circ} \mathrm{C}\right)$ is considerably lower than that of specialized water-transporting cells, such as renal tubules $\left(185-250 \mu \mathrm{m} \cdot \mathrm{s}^{-1}\right)$ $[25,26]$ and mammalian erythrocytes (120-530 $\left.\mu \mathrm{m} \cdot \mathrm{s}^{-1}\right)[27,28]$ and is in the range of diffusional water permeability across lipid bilayers and liposomes $\left(2-50 \mu \mathrm{mm} \cdot \mathrm{s}^{-1}\right)$ [1]. However, the observed $E_{\mathrm{a}}$ $\left(\sim 3.8 \mathrm{kcal} \cdot \mathrm{mol}^{-1}\right)$ is much lower than the values for lipid membranes without functioning water channels $\left(8-15 \mathrm{kcal} \cdot \mathrm{mol}^{-1}\right)$ [1], and indicates that the energy barrier of water crossing the cardiac sarcolemma is as low as the value for free-water difusion $(\sim 4$ $\left.\mathrm{kcal} \cdot \mathrm{mol}^{-1}\right)$. Furthermore, treatment with $\mathrm{Hg}^{2+}$, a sulfhydryl reagent commonly used to block water channels $[4,19]$, inhibited $P_{\mathrm{f}}$ by $\sim 90 \%$ and increased $E_{\mathrm{a}}$ to $12 \mathrm{kcal} \cdot \mathrm{mol}^{-1}$. Taken together, these data indicate that water crosses guinea pig myocyte membranes mainly by the water-channel-mediated mechanism.

Suleymanian and Baumgarten [18] measured sarcolemmal hydraulic conductivity $\left(L_{\mathrm{p}}\right)$ from rabbit ventricular myocytes and obtained a low value $\left(L_{\mathrm{p}}\right.$ of $1.2 \times 10^{-10} l \cdot \mathrm{N}^{-1} \cdot \mathrm{s}^{-1}$, equivalent to $P_{\mathrm{f}}$ of $16 \mu \mathrm{m} \cdot \mathrm{s}^{-1}$ at $22^{\circ} \mathrm{C}$ ) that is comparable to the guinea pig $P_{\mathrm{f}}$ 
$\left(12 \mu \mathrm{m} \cdot \mathrm{s}^{-1}\right.$ at $\left.22^{\circ} \mathrm{C}\right)$. However, they obtained higher $E_{\mathrm{a}}\left(12 \mathrm{kcal} \cdot \mathrm{mol}^{-1}\right)$ and thereby concluded that the primary route for water crossing cardiac membranes is directly through the lipid bilayers. There are no substantial differences in experimental conditions and data acquisition between their study and ours; data analysis is also unlikely to be a factor because the calculation of $L_{\mathrm{p}}$ from the guinea pig data by using their formula still gives a low $E_{\mathrm{a}}\left(\sim 3.7 \mathrm{kcal} \cdot \mathrm{mol}^{-1}\right)$. Thus the divergence is most likely to be due to species difference in the expression of sarcolammal water channels. From the single-channel $P_{\mathrm{f}}$ of aquaporin-1 $\left(\sim 10^{-13} \mathrm{~cm}^{3} \cdot \mathrm{s}^{-1}\right)[29]$ and the $\mathrm{Hg}^{2+}$-inhibited $P_{\mathrm{f}}$ of $\sim 12 \mu \mathrm{m} \cdot \mathrm{s}^{-1}$ at room temperature, a density of aquaporin monomer is estimated to be $120 \mu \mathrm{m}^{-2}$ for guinea pig myocyte membranes. This estimate is roughly an order of magnitude greater than the membrane density of cardiac ionic channels, but much less than the density of aquaporin-1 in erythrocytes $\left(\sim 2 \times 10^{5}\right.$ monomers per erythrocyte, corresponding to $\sim 1,500 \mu \mathrm{m}^{-2}$ ) [3, 29]. If the density of aquaporin in cardiac membranes is $10 \mu \mathrm{m}^{-2}$ rather than 120 $\mu \mathrm{m}^{-2}$, it would make a physiologically insignificant contribution to myocyte $P_{\mathrm{f}}\left(\sim 1 \mu \mathrm{m} \cdot \mathrm{s}^{-1}\right)$.

Unstirred layer effects are another concern in the low myocyte $P_{\mathrm{f}}$. It is believed that the osmotic water flow sweeps solute toward unstirred layers adjacent to the membrane on one side and away from the membrane on the other $[2,30]$. These "sweeping-away" effects act to reduce the osmotic gradient around the cell surface and can lead to an underestimation of $P_{\mathrm{f}}$. The experimentally observed $P_{\mathrm{f}}\left(P_{\mathrm{f}(\mathrm{obs})}\right)$ is described as $P_{\mathrm{f}(\mathrm{obs})}=P_{\mathrm{f}(\mathrm{memb})} \exp \left(-J_{\mathrm{v}} \delta / D_{\mathrm{s}}\right)$, where $P_{\mathrm{f}(\mathrm{memb})}$ is the true membrane, $P_{\mathrm{f}}, J_{\mathrm{v}}$ is the water volume flux, $\delta$ is the thickness of the unstirred layer, and $D_{\mathrm{s}}$ is the diffusion coefficient of the osmolyte [2]. $J_{\mathrm{v}}$ was calculated from the time course of cell swelling and shrinkage, $\delta$ from $\delta=\left(D_{\mathrm{s}} \cdot t_{0.9}\right)^{0.5}$ where $t_{0.9}$ is the time for the concentration to reach $90 \%$ of its steady-state value, and $D_{\mathrm{s}}$ from the concentration-weighted average of the diffusion coefficient $\left(25^{\circ} \mathrm{C}\right)$ of $\mathrm{NaCl}(1.612 \times$ $\left.10^{-5} \mathrm{~cm}^{2} \cdot \mathrm{s}^{-1}\right)$ and sucrose $\left(0.523 \times 10^{-5} \mathrm{~cm}^{2} \cdot \mathrm{s}^{-1}\right)$ in $0.5 \mathrm{~T}, 2.2 \mathrm{~T}$, and $4 \mathrm{~T}$ solutions. The calculated $P_{\mathrm{f}(\mathrm{memb})}$ was $12.7,11.9$, and $11.9 \mu \mathrm{m} \cdot \mathrm{s}^{-1}$ at $22^{\circ} \mathrm{C}$ in $0.5 \mathrm{~T}$, $2.2 \mathrm{~T}$, and $4 \mathrm{~T}$ solutions, respectively (vs. $P_{\mathrm{f}(\mathrm{obs})}$ of 12.6 , 11.7 , and $11.9 \mu \mathrm{m} \cdot \mathrm{s}^{-1}$, respectively; see RESULTS); the differences between $P_{\mathrm{f}(\mathrm{memb})}$ and $P_{\mathrm{f}(\mathrm{obs})}$ are $<2 \%$ and may be negligible, as estimated earlier for rabbit ventricular myocytes $(<3 \%)$ [18].

Physiological and pathophysiological implications. Renal tubules, for example, require high water permeability for the urine-concentrating mechanism $[3,31]$. In contrast, the low water perme- ability of cardiac membranes seems to be less important in physiological cell volume regulation because heart cells normally do not experience significant osmotic perturbations. However, it may have functional significance under pathophysiological conditions by restricting the rapidity of osmotic cell swelling and shrinkage. For example, cardiac ischemia and reperfusion cause cell swelling and membrane disruption [32]; the intracoronary injection of hyperosmotic radiocontrast medium results in side effects on electromechanical activities [33]. Transient osmotic disturbances underlying these events would be exacerbated if the water permeability was high. Recently, the regulation of water channel function is thought to be a potential therapeutic strategy for a variety of cardiovascular disorders, including congestive heart failure, hypertension, lung edema, and brain swelling [5, 34]. Further investigation is warranted because abnormalities in osmotic and volume homeostasis can have consequences for heart cell function.

This work was supported by a Grant-in-Aid for Scientific Research from the Ministry of Education, Culture, Sports, Science and Technology of Japan (No. 13670751 to T.O.).

\section{REFERENCES}

1. Fettiplace $R$ and Haydon DA: Water permeability of lipid membranes. Physiol Rev 60: 510-550, 1980

2. Finkelstein A: Water Movement through Lipid Bilayers, Pores, and Plasma Membranes: Theory and Reality, John Wiley and Sons, New York, pp 10-31, 155-184, 1987

3. Agre P, Preston GM, Smith BL, Jung JS, Raina S, Moon C, Guggino WB, and Nielsen S: Aquaporin CHIP: the archetypal molecular water channel. Am J Physiol 265: F463-F476, 1993

4. Macey RI: Transport of water and urea in red blood cells. Am J Physiol 246: C195-C203, 1984

5. Verkman AS and Mitra AK: Structure and function of aquaporin water channels. Am J Physiol Renal Physiol 278: F13-F28, 2000

6. Bondy C, Chin E, Smith BL, Preston GM, and Agre P: Developmental gene expression and tissue distribution of the CHIP28 water-channel protein. Proc Natl Acad Sci USA 90: 4500-4504, 1993

7. Hasegawa $\mathrm{H}$, Lian SC, Finkbeiner WE, and Verkman AS: Extrarenal tissue distribution of CHIP28 water channels by in situ hybridization and antibody staining. Am J Physiol 266: C893-C903, 1994

8. Ma T, Yang B, and Verkman AS: Cloning of a novel water and urea-permeable aquaporin from mouse expressed strongly in colon, placenta, liver, and heart. Biochem Biophys Res Commun 240: 324-328, 1997

9. Page E, Winterfield J, Goings G, Bastawrous A, and Upshaw-Earley J: Water channel proteins in rat cardiac myocyte caveolae: osmolarity-dependent reversible internalization. Am J Physiol 274: H1988-H2000, 1998 


\section{T. OGURA, S. IMANISHI, and T. SHIBAMOTO}

10. Ogura T, You Y, and McDonald TF: Membrane currents underlying the modified electrical activity of guinea-pig ventricular myocytes exposed to hyperosmotic solution. J Physiol (Lond) 504: 135-151, 1997

11. Solomon AK: Water channels across the red blood cell and other biological membranes. Methods Enzymol 173: 192-222, 1989

12. Agre P, Mathai JC, Smith BL, and Preston GM: Functional analyses of aquaporin water channel proteins. Methods Enzymol 294: 550-572, 1999

13. Isenberg $\mathrm{G}$ and Klockner U: Calcium tolerant ventricular myocytes prepared by preincubation in a "KB medium." Pflügers Arch 395: 6-18, 1982

14. Boyett MR, Frampton JE, and Kirby MS: The length, width and volume of isolated rat and ferret ventricular myocytes during twitch contractions and changes in osmotic strength. Exp Physiol 76: 259-270, 1991

15. Roos KP: Length, width, and volume changes in osmotically stressed myocytes. Am J Physiol 251: H1373-H1378, 1986

16. Tanaka R, Barnes MA, Cooper Gt, and Zile MR: Effects of anisosmotic stress on cardiac muscle cell length, diameter, area, and sarcomere length. Am J Physiol 270: $\mathrm{H} 1414-\mathrm{H} 1422,1996$

17. Drewnowska $\mathrm{K}$ and Baumgarten $\mathrm{CM}$ : Regulation of cellular volume in rabbit ventricular myocytes: bumetanide, chlorothiazide, and ouabain. Am J Physiol 260: C122-C131, 1991

18. Suleymanian MA and Baumgarten CM: Osmotic gradient-induced water permeation across the sarcolemma of rabbit ventricular myocytes. J Gen Physiol 107: 503514, 1996

19. Preston GM, Jung JS, Guggino WB, and Agre P: The mercury-sensitive residue at cysteine 189 in the CHIP28 water channel. J Biol Chem 268: 17-20, 1993

20. Sorenson AL, Tepper D, Sonnenblick EH, Robinson TF, and Capasso JM: Size and shape of enzymatically isolated ventricular myocytes from rats and cardiomyopathic hamsters. Cardiovasc Res 19: 793-799, 1985

21. Sperelakis N and Rubio R: Ultrastructural changes produced by hypertonicity in cat cardiac muscle. J Mol Cell Cardiol 3: 139-156, 1971
22. Silver LH, Hemwall EL, Marino TA, and Houser SR: Isolation and morphology of calcium-tolerant feline ventricular myocytes. Am J Physiol 245: H891-H896, 1983

23. Hille B: Ionic Channels of Excitable Membranes, Sinauer Associates Inc., Sunderland, MA, pp 9-11, 1992

24. Satoh H, Delbridge LM, Blatter LA, and Bers DM: Surface:volume relationship in cardiac myocytes studied with confocal microscopy and membrane capacitance measurements: species-dependence and developmental effects. Biophys J 70: 1494-1504, 1996

25. Hebert SC and Andreoli TE: Water movement across the mammalian cortical collecting duct. Kidney Int 22: 526-535, 1982

26. Verkman AS and Ives HE: Water permeability and fluidity of renal basolateral membranes. Am J Physiol 250: F633-F643, 1986

27. Farmer RE and Macey RI: Perturbation of red cell volume: rectification of osmotic flow. Biochim Biophys Acta 196: 53-65, 1970

28. Tsai ST, Zhang RB, and Verkman AS: High channel-mediated water permeability in rabbit erythrocytes: characterization in native cells and expression in Xenopus oocytes. Biochemistry 30: 2087-2092, 1991

29. van Hoek AN and Verkman AS: Functional reconstitution of the isolated erythrocyte water channel CHIP28. J Biol Chem 267: 18267-18269, 1992

30. Barry PH and Diamond JM: Effects of unstirred layers on membrane phenomena. Physiol Rev 64: 763-872, 1984

31. Verkman AS: Mechanisms and regulation of water permeability in renal epithelia. Am J Physiol 257: C837C850, 1989

32. Garcia-Dorado D and Oliveras J: Myocardial oedema: a preventable cause of reperfusion injury? Cardiovasc Res 27: 1555-1563, 1993

33. Lieberman PL and Seigle RL: Reactions to radiocontrast material. Anaphylactoid events in radiology. Clin Rev Allergy Immunol 17: 469-496, 1999

34. Beitz E and Schultz JE: The mammalian aquaporin water channel family: a promising new drug target. Curr Med Chem 6: 457-467, 1999 